\title{
Schedule UTP: Stock Price Reaction and Economic Consequences
}

\author{
John L. Abernathy, Stephan A. Davenport, and Eric T. Rapley
}

\begin{abstract}
In 2010, the Internal Revenue Service (IRS) announced the requirement to disclose uncertain tax positions (UTP) on a new schedule (Schedule UTP) to be filed with federal corporate income tax returns. Schedule UTP could increase a firm's tax burden by providing a roadmap for the IRS to identify firms' tax-planning strategies. We find that stock returns around the development of Schedule UTP are negative, consistent with investors' concern that Schedule UTP would impose costs on firms. However, we document a significant positive stock price reaction to the release of the final draft of Schedule UTP in which the IRS relaxed many of the controversial provisions of Schedule UTP. Additionally, we find this positive reaction is incrementally larger for more taxaggressive firms. Finally, we find a significant decrease in reported unrecognized tax benefits (UTBs) and additions to UTBs after the adoption of Schedule UTP in 2010.
\end{abstract}

Keywords: Schedule UTP; tax avoidance; uncertain tax positions; event study.

\section{INTRODUCTION}

$\mathrm{T}$ his study investigates the effects of Schedule UTP on (1) firm value and (2) firm reporting behavior. During 2010, the Internal Revenue Service (IRS) released a series of announcements proposing a new schedule (Schedule UTP) requiring all corporate taxpayers with assets greater than $\$ 10$ million to disclose to the IRS all uncertain tax positions (UTPs) affecting their federal tax liability. ${ }^{1}$ The stated purpose of Schedule UTP was to improve

John L. Abernathy is an Assistant Professor at Oklahoma State University, Stephan A. Davenport is a Ph.D. Candidate at The University of Alabama, and Eric T. Rapley is a Ph.D. Candidate at Oklahoma State University.

We gratefully acknowledge helpful comments from two anonymous journal referees and John Phillips (editor). We also thank two anonymous conference referees, Pete Frischmann (discussant), and participants at the 2012 Journal of the American Taxation Association Midyear Meeting. We also appreciate comments from Brad Blaylock, Mike Donohoe, Katharine Drake, Mike Dugan, Amy Dunbar, Lauren Gorman, Rick Hatfield, Don Herrmann, Rich Houston, Susan Jurney, Tom Lopez, Sandeep Nabar, Linda Parsons, Austin Reitenga, Ed Schnee, Mary Stone, Gary Taylor, Ryan Wilson, and workshop participants at The University of Alabama.

Submitted: December 2011 Accepted: June 2012 Published Online: July 2012

\footnotetext{
${ }^{1}$ A UTP is any tax position taken by a firm that could be challenged by the IRS upon examination. Although unrecognized tax benefits (UTBs) and uncertain tax positions (UTPs) are similar and sometimes used interchangeably in the literature, for clarity we refer to financial statement disclosures as UTBs and IRS disclosures as UTPs.
} 
the efficiency and effectiveness of IRS corporate tax audits (Harvey 2011). However, many corporations and practitioners expressed concern that this disclosure would significantly increase the complexity of preparing the tax return and the obligations of the return preparers (KPMG 2010), as well as increase future corporate tax burdens (Edwards et al. 2010). Accordingly, our initial test uses an event study methodology to investigate market participants' perceptions of the benefits and costs of Schedule UTP. ${ }^{2}$

Although Schedule UTP does not require any additional disclosures to the public, a substantial amount of new information concerning UTPs is reported to the IRS. Specifically, as originally proposed, ${ }^{3}$ the new schedule required a description of each UTP and the maximum liability to which the firm could be exposed if the position was disallowed upon examination. Disclosure would be required not only for tax positions for which the firm has recorded a reserve in its financial statements, but also for positions for which no reserve has been recorded in the financial statements because the firm expects to litigate the issue or there is administrative practice not to audit the issue. In essence, Schedule UTP would require companies to report a concise description to the IRS of each item that comprises the aggregate UTB recorded in the audited financial statements (KPMG 2010). These requirements signal the IRS's intention to increase the scrutiny of reported UTBs, and therefore have the potential to change reporting behavior for firms recording these reserves in their financial statements. Accordingly, we also investigate whether firms alter the UTBs disclosed in their financial statements as a result of this mandatory change in tax return disclosures.

This study is closely related to Edwards et al. (2010), who also examine the stock price reaction to the initial Schedule UTP announcement; however, there are several key differences between our study and their study. First, they examine only the initial date of the proposed Schedule UTP (Announcement 2010-9). Our study not only examines the initial announcement, but also the release of the draft form and instructions for Schedule UTP, and the final form and instructions for Schedule UTP. As noted in Donohoe and McGill (2011), examining the market reaction to news released on multiple event dates is important before making inferences about the response of market participants. These dates are important in assessing the response of market participants because the original draft of Schedule UTP reaffirmed the controversial provisions of Schedule UTP despite many concerns raised by commenters. On the other hand, the final draft of Schedule UTP relaxed many of the more controversial provisions, which surprised many practitioners (Leone 2010). Second, due to data limitations, Edwards et al. (2010) only examine S\&P 500 firms. In contrast, our study examines the stock price reaction for all firms with assets greater than $\$ 10$ million, which is the IRS's disclosure threshold for Schedule UTP. This is an important difference because large firms (i.e., the S\&P 500 firms) are closely monitored by the IRS and are already subject to a high probability of an IRS audit. Therefore, changes in tax policy such as Schedule UTP may have a greater impact for smaller firms, which are included in our sample. Finally, our study examines financial reporting outcomes related to the new Schedule UTP. Specifically, we examine the change in reported UTBs in 2010, the first reporting period when Schedule UTP was announced and finalized.

Our study has three primary objectives. The first objective of our study is to document the general stock price response to the release of information about Schedule UTP. Using a sample of firms that would be required to file Schedule UTP according to Announcement 2010-9 (firms with total assets greater than $\$ 10$ million), we find evidence of a negative stock price reaction to the original announcement of Schedule UTP. Additionally, we find a positive stock price reaction to the final Schedule UTP rules, which relaxed many of the more controversial provisions of Schedule UTP.

\footnotetext{
2 We examine three separate IRS announcements related to the topic of Uncertain Tax Positions: Announcements 2010-9, 2010-30, and 2010-75. See Table 1 for dates and descriptions of each announcement.

3 There were significant modifications to Schedule UTP from the original proposal to the final draft. These modifications are discussed in more detail in the next section.
} 
The second objective of our study is to provide evidence regarding whether the market response to the announcement of Schedule UTP varies with a firm's tax aggressiveness. While multivariate analysis provides mixed evidence that the market believes that Schedule UTP will be more costly for tax-aggressive firms, we do note that the positive stock price response to the final draft of Schedule UTP is significantly positively associated with the tax-aggressive characteristics of our sample firms.

The third objective of our study is to provide evidence regarding whether firms change the level of UTBs reported in their financial statements subsequent to the implementation of Schedule UTP. One stated purpose of Schedule UTP is to improve the efficiency and effectiveness of IRS examinations. Therefore, firms have a greater incentive to report fewer new UTBs in 2010, because they are subject to greater IRS scrutiny as a result of Schedule UTP. Despite the fact that the IRS relaxed many of the more controversial provisions of Schedule UTP in the final draft and instructions, the release of Schedule UTP highlighted the IRS's intention to closely monitor UTBs reported by firms. Therefore, we predict and find a significant decrease in the level of reported UTBs subsequent to the adoption of Schedule UTP. This decrease is significant after controlling for changes in determinants of UTB identified in prior research. Additionally, multivariate tests provide evidence that current-year additions to reported UTBs decreased significantly after the adoption of Schedule UTP.

This study extends the literature on the valuation and consequences of changes in tax-reporting requirements. For example, Frischmann et al. (2008) examine the market reaction to various dates regarding the development and implementation of FIN 48 and find no significant initial market reaction. ${ }^{4}$ Similarly, Donohoe and McGill (2011) document a significant negative market reaction to the development of Schedule M-3. Donohoe and McGill $(2011,37)$ further note that "as regulators acquire new and/or update old sources of data in an effort to reduce the tax gap, it is important that we recognize the potential valuation effects of such enforcement efforts." Because Schedule UTP combines financial statement reporting with IRS reporting, this study is a natural extension of both Frischmann et al. (2008) and Donohoe and McGill (2011), and it provides additional evidence about the valuation effects of enforcement efforts.

Additionally, prior literature provides evidence that greater regulatory oversight induces real effects on firm behavior. For example, Blouin et al. (2010) provide evidence that firms settled disputes with the IRS and reduced UTBs prior to the adoption of FIN 48. Similarly, Donohoe and McGill (2011) document a significant reduction in book-tax differences around the development of Schedule M-3. This study provides evidence consistent with an IRS requirement (Schedule UTP) inducing financial reporting changes (decreased UTB).

The paper is organized as follows. The next section provides a brief background on Schedule UTP and discusses the selection of dates investigated in this study. The third section develops the hypotheses, and the fourth section provides a description of the sample selection and data used for the tests, as well as the research methodology. The fifth section presents the results, and the final section concludes the paper.

\section{BACKGROUND OF SCHEDULE UTP AND SELECTION OF EVENT DATES}

\section{Development of Schedule UTP}

On July 14, 2006, the Financial Accounting Standards Board (FASB) issued Interpretation No. 48, Accounting for Uncertainty in Income Tax Positions-An Interpretation of FASB Statement No. 109 (FIN 48), which was effective for years beginning after December 15, 2006. FIN 48 required

\footnotetext{
${ }^{4}$ In their subsequent analysis of Congressional hearings regarding FIN 48, Frischmann et al. (2008) conclude that investors believed that additional regulation could be coming in the future. Our results support the notion that investors believe Schedule UTP provides the "roadmap" to the IRS that FIN 48 did not.
} 
that firms disclose in the tax footnotes to financial statements all unrecognized tax benefits resulting from uncertain tax positions. ${ }^{5}$ Critics of FIN 48 argued that the mandatory UTB disclosures would provide a roadmap of uncertain tax positions to tax authorities (Frischmann et al. 2008). It is not clear, however, that these concerns were valid. Because the FIN 48 disclosures do not identify the positions by jurisdiction or entity in the firm's consolidated financial statements, it is unlikely that the FIN 48 disclosures would help any single tax authority identify specific aggressive tax positions (Dunbar and Massel 2011).

Consistent with this notion, Frischmann et al. (2008) find little evidence of a stock price reaction to events leading to the adoption of FIN 48. They do, however, document a significant negative market reaction for their sample of firms to news regarding the Senate Investigative subcommittee's request for additional information regarding UTB disclosures. They interpret this finding as evidence that investors reacted negatively because the inquiry could ultimately lead to Congress enacting new tax rules targeted at the transactions underlying the UTB.

Toward that end, the IRS established a new reporting requirement for companies to disclose their uncertain tax positions on Schedule UTP. This initiative was first announced on January 26, 2010, when the IRS issued Announcement 2010-9 (IRS 2010a). On April 19, 2010, the IRS issued Announcement 2010-30, which provided an initial draft Schedule UTP and accompanying instructions for completing this new disclosure schedule (IRS 2010b). On September 24, 2010, after considering a number of taxpayer comments, the IRS issued Announcement 2010-75 (IRS 2010c), which finalized the taxpayer disclosure requirements for completing the final Schedule UTP. The IRS also issued Announcement 2010-76 (IRS 2010d) on September 24, 2010, which outlined modifications to the IRS's policy of restraint. ${ }^{6}$ Treasury Regulation Section 1.6012-2(a)(4) requires a corporation to attach Schedule UTP, Uncertain Tax Position Statement, to its tax return "in accordance with forms, instructions, or other appropriate guidance provided by the IRS." This disclosure requirement applies to returns filed for tax years beginning on or after January 1, 2010.

Table 1 provides a listing of each IRS announcement associated with Schedule UTP that we examine in our study, and our prediction regarding whether the event elicited a positive or negative market reaction. ${ }^{7}$ The following section provides a complete discussion of each IRS announcement. The predicted signs in both Table 1 and our hypothesis testing are based on the assumption that tax and compliance costs are positively related to Schedule UTP disclosure requirements.

\section{HYPOTHESIS DEVELOPMENT}

\section{Hypothesis Development for the Proposal of Schedule UTP}

On January 26, 2010, the IRS released Announcement 2010-9, which proposed an initiative that required reporting uncertain tax positions to the IRS. Under this proposal, all firms with total assets greater than $\$ 10$ million would be required to file a new schedule that provides: (1) a concise description, including rationale, of each uncertain tax position for which the taxpayer or a related entity has recorded a reserve in its financial statements; and (2) the maximum amount of potential federal tax liability attributable to each uncertain tax position. In addition, firms must also disclose

\footnotetext{
5 FIN 48 defined the term "UTB" and standardized its reporting. Prior research has referred to UTBs as a "tax cushion" or "tax reserve."

6 The final draft and clarifications were included in two separate IRS announcements, Announcement 2010-75 and Announcement 2010-76. These announcements were made on the same day; therefore, for clarity, we refer to the final draft as Announcement 2010-75.

7 Although it is possible that investors knew about the announcements prior to their release date, we performed an extensive search of the LexisNexis database and find no mention of the announcements prior to their release date. Consequently, we believe that the release dates of the individual announcements are the dates on which information about Schedule UTP was publicly disseminated.
} 


\section{TABLE 1}

\section{Important Events Relating to the Release of Schedule UTP}

\begin{tabular}{lll}
$\frac{\text { Event Date }}{1 / 26 / 10}$ & \multicolumn{1}{c}{ Description } & $\begin{array}{c}\text { Expected St } \\
\text { Price React }\end{array}$ \\
& $\begin{array}{l}\text { IRS Announcement 2010-9 is released, which required corporations to } \\
\text { disclose uncertain tax positions on Schedule UTP beginning in tax year } \\
2010 .\end{array}$ & Negative \\
4/19/10 & $\begin{array}{l}\text { IRS Announcement 2010-30 is released, which set forth an initial draft } \\
\text { Schedule UTP and accompanying instructions for completing this new } \\
\text { disclosure schedule. This draft requires firms to disclose all uncertain tax } \\
\text { positions as well as the uncertainty and nature of each position. Firms were }\end{array}$ & \\
also required to disclose the maximum tax adjustment for each position. & Positive \\
9/24/10 & $\begin{array}{l}\text { IRS Announcements 2010-75 and 2010-76 are released, which provide final } \\
\text { disclosure requirements for completing Schedule UTP. The final draft } \\
\text { eliminated the requirement that firms disclose the maximum tax adjustment } \\
\text { for each position. It simply requires a description of each position. }\end{array}$
\end{tabular}

This table summarizes important events relating to the promulgation Schedule UTP and our expectations of the market's reaction during the three-day window surrounding each event.

any uncertain position for which they had not recorded a reserve due to IRS administrative practice or the firm's intent to litigate (IRS Announcement 2010-9).

According to Commissioner Shulman, Schedule UTP will benefit the IRS and the taxpayers in several ways. First, Schedule UTP will create certainty sooner on uncertain tax positions. Similarly, Schedule UTP will reduce the time it takes to complete an audit, which will benefit taxpayers. Finally, Schedule UTP will not increase compliance costs because much of the information requested is already being gathered for FIN 48 disclosure (Shulman 2010).

This announcement, however, caught many practitioners, tax executives, and commentators by surprise (TEI 2010). A major area of concern involved how the new information would be used by the IRS, and how the existing "policy of restraint" related to tax accrual work papers would be affected. For example, Alston and Bird $(2010,2)$ note that "any description that contains the taxpayer's rationale or reasons underlying a UTP threatens to reveal an adviser's confidential advice or mental impressions, conclusions, and opinions, which are at the very core of what is protected and intended to be protected by attorney-client privilege, federal tax practitioner privilege, and work product privilege." A second area of concern focused on the increased reporting burden placed on firms. For example, Miller and Chevalier $(2010,1)$ note "the requirement that taxpayers disclose issues for which no reserve is recorded would be unduly burdensome for taxpayers and is inconsistent with the policy behind the proposed adoption of Schedule UTP."

Furthermore, the initial Schedule UTP would potentially increase several costs for companies. For example, companies may experience an increase in compliance costs for filing their federal tax returns. The proposed schedule could also significantly increase the complexity of preparing the tax return and the obligations of the return preparers (KPMG 2010). ${ }^{8}$ Similarly, Schedule UTP can increase compliance costs through audit and tax preparation fees. If companies use their FIN 48 information as the basis for the new schedule, auditors and tax preparers are likely to devote more

\footnotetext{
${ }^{8}$ While Schedule UTP builds upon FIN 48 disclosures, which are already required, it could potentially require more work because the accounting rule only requires disclosure of aggregate reserve amounts, not itemized data.
} 
time to examining the content of the FIN 48 disclosure. In addition to increases in compliance costs, income tax costs can also be affected by Schedule UTP. According to Commissioner Shulman, the goals of Schedule UTP are to prioritize selection of taxpayers and issues to audit, and to improve IRS audit efficiency (Shulman 2010). This increased efficiency not only could increase proposed tax audit adjustments, but also cause firms to take fewer uncertain tax positions. Both of these would cause firms to pay more in income taxes.

Prior research has shown that increased regulation is more costly for tax-aggressive firms. For example, Donohoe and McGill (2011) examine the market reaction to announcements related to the implementation of Schedule M-3 by the IRS and note that tax-aggressive firms, as proxied by permanent book-tax differences, experience a more significant negative market reaction. Slemrod (2004) and Chen and Chu (2005) provide theoretical support for this finding by showing analytically that tax avoidance is negatively associated with detection risk. To the extent that Announcement 2010-9 impacts detection risk, firms should engage in less tax avoidance, which will in turn increase federal income tax expense. Thus, we expect firms that are more tax aggressive will have more negative stock price reaction to Announcement 2010-9.

In sum, there are several potential costs that would increase as a result of Announcement 20109. Ceteris paribus, an increase in costs will result in lower future cash flows. We further expect that the potential costs will be greater for firms that investors view as tax aggressive. Therefore, our first hypotheses stated in alternative form are:

H1: There is a negative stock price reaction surrounding Announcement 2010-9.

H1a: The stock price reaction surrounding Announcement 2010-9 is more negative for firms investors believe are more tax aggressive.

\section{Hypothesis Development for the Preliminary Draft of Schedule UTP}

On April 19, 2010, the IRS released Announcement 2010-30, which included a draft Schedule UTP and Instructions. While the announcement addressed comments received from the previous release regarding duplicate disclosures, retroactivity, and computations on valuation and transfer pricing issues, it did not specifically reduce any requirements from the original announcement. In effect, Announcement 2010-30 increased the saliency of Schedule UTP and promulgated concerns that Schedule UTP would be a roadmap for the IRS to identify taxpayers' most important tax issues. Thus, we expect a negative stock price reaction to Announcement 2010-30. We again expect that the potential costs will be greater for more tax-aggressive firms. Therefore, our second hypotheses stated in alternative form are:

H2: There is a negative stock price reaction surrounding Announcement 2010-30.

H2a: The stock price reaction surrounding Announcement 2010-30 is more negative for firms investors believe are more tax aggressive.

\section{Hypothesis Development for the Final Draft of Schedule UTP}

On September 24, 2010, the IRS released two announcements (Announcements 2010-75 and 2010-76) unveiling a number of important changes to the final Schedule UTP and Instructions. The major changes included a five-year phase-in of the reporting requirement based on a corporation's asset size, ${ }^{9}$ no reporting of a maximum tax adjustment, no reporting of the rationale and nature of uncertainty in the concise description of the position, and no reporting of administrative practice tax

\footnotetext{
9 Specifically, corporations having assets of $\$ 100$ million were required to file for 2010 . The asset threshold is lowered to $\$ 50$ million for 2012 , and finally to $\$ 10$ million for 2014 .
} 
positions (IRS Announcement 2010-75). The final rules also specified that Schedule UTP need only report uncertain tax positions taken in the current year, even if a reserve for a prior-year tax position is recorded in the audited financial statements.

Additionally, Announcement 2010-76 clarified the IRS policy of restraint by stating that it would not seek particular documents that relate to UTPs and the otherwise privileged work papers that document the completion of Schedule UTP (IRS Announcement 2010-76). Other than requiring the disclosure of the information on the schedule, the IRS noted that the requirement to file Schedule UTP does not affect the policy of restraint. Specifically, the IRS stated that taxpayers may redact specific confidential information from copies of tax reconciliation work papers relating to the preparation of Schedule UTP that they are asked to produce during an examination.

These announcements relaxed many of the more controversial provisions of Schedule UTP and were generally viewed as favorable by interested parties (Harvey 2011). Many experts were surprised by how responsive the IRS was to the comments it received on the draft schedule, in particular that it eliminated the requirement to disclose maximum tax adjustments (Leone 2010). One commenter noted that the IRS revised its proposal on uncertain tax positions in a way that is much more favorable to corporations (Sidley and Austin 2011).

Because the final Schedule UTP relaxed many provisions of the original proposal that could potentially affect income tax costs, we expect a positive stock price reaction to the final draft of Schedule UTP. We expect that this effect will be more pronounced for more tax-aggressive firms, which should benefit more from the relaxed provisions. Therefore, our third hypotheses stated in alternative form are:

H3: There is a positive stock price reaction surrounding Announcement 2010-75.

H3a: The stock price reaction surrounding Announcement 2010-75 is more positive for firms investors believe are more tax aggressive.

\section{Hypothesis Development for the Changes in Financial Reporting Behavior Subsequent to the Adoption of Schedule UTP}

If Schedule UTP improves the efficiency and effectiveness of IRS examinations, the IRS will not only be able to select more companies to audit, but they will potentially generate more tax revenue from the firms that are selected for audit. Additionally, firms that currently take uncertain tax positions might become more conservative in those positions because of the increase in detection risk of overly aggressive tax positions (Slemrod 2004; Chen and Chu 2005). ${ }^{10}$ Toward that end, Blouin et al. (2010) show that firms significantly decreased UTBs in the year prior to the adoption of FIN 48. Similarly, Harvey (2011) suggests that corporations will attempt to avoid disclosure on Schedule UTP because they are not anxious to discuss uncertain tax positions with the IRS. Another commenter suggests that if establishing a financial statement reserve under Schedule UTP significantly increases the probability of an IRS challenge, then judgments about whether to establish a reserve will inevitably be affected (Cravath, Swaine \& Moore 2010). Therefore, we expect that the level of UTBs reported by a firm will decrease subsequent to the adoption of Schedule UTP. That is, firms will have a greater incentive to decrease their reported UTBs in 2010 because they will be subject to greater IRS scrutiny. ${ }^{11}$ Therefore, our final hypothesis stated in alternative form is:

${ }^{10}$ Currently, there is no specific penalty for failing to file a required Schedule UTP or disclosing all uncertain tax positions. However, the IRS does have the ability to impose accuracy-related penalties. Therefore, it is likely that the IRS will assert penalties against a corporate taxpayer that has failed to disclose a position as being uncertain when the IRS proposes a substantial audit adjustment with respect to the tax issue.

11 While the IRS subsequently relaxed some of the more controversial provisions of Schedule UTP, as discussed in the previous sections, the release of Schedule UTP did highlight the intention of the IRS to closely monitor UTPs, which could affect the level of UTBs taken by firms. 
H4: UTBs disclosed in the financial statements will decline subsequent to the adoption of Schedule UTP.

\section{SAMPLE SELECTION AND METHODOLOGY}

\section{Sample}

Sample selection begins with all firms available in the Industrial Annual file of Compustat for fiscal year 2010. Because Schedule UTP was originally applicable to firms with assets of $\$ 10$ million or greater, we limit our analysis to these firms. For inclusion in our stock price reaction sample, we require each observation to have at least one of our measures of tax aggression and daily stock price data (from CRSP) for all three event dates. H1-H3 will be tested with this stock price reaction sample, which contains 3,752 firms.

Testing $\mathrm{H} 4$ restricts the number of firms because it requires reported UTBs and additional variables to control for determinants of UTB. We further require that firms have data available from 2007 to 2010 . We impose this restriction so that we can more cleanly test firm-specific changes in UTB reporting and avoid the possibility that our results are influenced by the increased coverage of UTBs in Compustat. ${ }^{12}$ Finally, we limit our financial reporting sample to firms with greater than $\$ 100$ million in total assets because only these firms were required to file Schedule UTP in 2010. Limiting our tests to a constant sample of firms (i.e., firms with all available data for 2007-2010) reduces the UTB reporting sample to 1,267 firms (5,068 observations). ${ }^{13}$ See Appendix A for additional details regarding calculations and data availability for the variables.

\section{Tax Aggressiveness}

We use two proxies for tax aggressiveness found in the extant literature. ${ }^{14}$ Because Schedule UTP builds on the requirements of FIN 48, our first proxy for tax aggressiveness is the amount of UTBs disclosed in the financial statement footnotes. UTBs are a relatively new measure of tax aggressiveness brought about by the financial statement disclosure requirements of FIN 48. Cazier et al. (2009) document that the level of UTBs reported in the financial statements is related to characteristics that prior research has shown are significantly associated with tax avoidance activities (Graham and Tucker 2006; Wilson 2009; Lisowsky et al. 2011). Following Lisowsky et al. (2011), we use the total amount of UTBs as a proxy for tax aggressiveness. ${ }^{15}$

Unlike most proxies for tax aggressiveness, UTBs provide a measure of a firm's tax aggressiveness directly from the financial statements because they represent management's beliefs about the riskiness of the tax positions they have taken (Frischmann et al. 2008). However, because UTBs are accruals used for financial accounting and reported in the footnotes, they also are subject to management's judgment, manipulation, and reporting discretion (Hanlon and Heitzman 2010). While this criticism is true for all proxies that rely on the tax information disclosed in the firm's financial statements, Lisowsky et al. (2011) find evidence that suggests aggressive financial reporting does not impact the usefulness of UTBs for inferring tax sheltering activities. Additionally, the use of UTBs is appropriate because, according to Chief Counsel for the IRS

${ }^{12}$ For firms with all the control variables, Compustat UTB coverage increased 60 percent from 2007 to 2010 , from approximately 1,700 firms in 2007 to 2,700 in 2010 .

${ }^{13}$ Using a sample of all firms with data available on Compustat from 2007-2010, i.e., not requiring four years of data or $\$ 100$ million in total assets, produces similar results to our constant sample. This finding supports the notion that firms may reduce reported UTBs in anticipation of filing Schedule UTP.

14 In order for the market reaction to vary as a function of a firm's tax aggressiveness, investors must be able to estimate firms' tax aggressiveness. Therefore, our tax aggressiveness measures are calculated with 2009 financial statement data, which would be available to investors for all event dates.

15 As a sensitivity analysis, we also use the amount of UTBs that would affect the firm's effective tax rate if recognized. This measure is highly correlated with the level of UTBs reported, and our results are similar. 
William Wilkins, the requirements of the new schedule are designed to supplement what firms were already required to account for under the requirements of FIN 48 (KPMG 2010).

Our second proxy for tax aggressiveness is permanent book-tax differences (PERMBTD). Permanent BTDs are defined as total book-tax differences (BTDs) less deferred income taxes divided by the statutory tax rate (35 percent), scaled by ASSETS ${ }_{t-1}$. Total BTDs measure both permanent and temporary differences between financial reporting and tax reporting. Temporary BTDs often reflect differences in reporting rules (e.g., depreciation); therefore, they may not reflect aggressive tax planning. ${ }^{16}$ On the other hand, permanent book-tax differences arise from fundamental differences in the income or expense items under the financial and tax-reporting systems (Mills and Plesko 2003). Specifically, permanent book-tax differences arise when reported book income is increased without a related increase in taxable income (Shevlin 2002; Boynton and Mills 2004; McGill and Outslay 2004).

Prior research indicates that large, positive BTDs signal tax aggressiveness. For example, Wilson (2009) documents that firms actively engaged in tax sheltering report larger BTDs. Desai (2003) suggests that the divergence of book-tax income in the 1990s was attributable to increased tax sheltering rather than to the traditional drivers of book-tax differences, such as depreciation and tax-exempt interest. Further, Heltzer (2009) and Frank et al. (2009) suggest that BTDs provide insight into a firm's relative level of tax aggressiveness. Favorable permanent differences are associated with transactions likely to be of interest to the IRS, so these firms face a higher probability of scrutiny (Donohoe and McGill 2011).

\section{Stock Price Response of Sample Firms}

To test H1, H2, and H3, we employ the Multivariate Regression Model (MVRM) proposed by Schipper and Thompson (1983), which has been used extensively in prior research (e.g., Frischmann et al. 2008; Li et al. 2008; Donohoe and McGill 2011). The MVRM methodology uses a dummy variable equal to 1 for key event dates, and 0 otherwise, to condition the return generating process on the occurrence or nonoccurrence of an event (Espahbodi et al. 2002). The coefficient on each dummy variable measures the impact of each event on stock returns. We use a three-day window surrounding the event date (that is $t-1, t, t+1$ ) because the exact timing of the information release associated with each event is not clear. We estimate the stock price reaction using the following regression model: ${ }^{17}$

$$
R_{p t}=\alpha_{p}+\beta_{p} R_{m t}+\sum_{k=1}^{K} g_{p k} D_{k t}+e_{p t},
$$

where:

$R_{p t}=$ return on portfolio $p$ on day $t(t=1,2, \ldots, T) ; T$ is the total number of daily return observations from the beginning of January 2010 through December of 2010;

$\alpha_{p}=$ intercept coefficient for portfolio $p$;

$\beta_{p}=$ risk coefficient for portfolio $p$;

$R_{m t}=$ the return on the CRSP value-weighted portfolio on day $t$;

$g_{p k}=$ effect of event $k(k=1,2, \ldots, K)$ on portfolio $p$ 's return; that is, $g$ is an estimate of the abnormal return on the portfolio on event date $k ; K$ is the total number of events examined, which is three in this study;

\footnotetext{
16 As a sensitivity analysis, we also use the total BTD measure. This measure is highly correlated with PERMBTD, and our results are similar. For brevity, these results are not tabulated.

17 We obtain similar results using the model employed by Donohoe and McGill (2011) that uses the Fama and French (1993) three-factor model rather than the return on the CRSP value-weighted portfolio.
} 
$D_{k t}=$ dummy variable for the $k$ th event set equal to 1 during the three-day period $(t=-1,0,+1$ relative to the announcement date), and 0 otherwise; and

$e_{p t}=$ random disturbance assumed to be both normal and independent of the explanatory variables.

Equation (1) estimates the impact of the key pronouncements associated with Schedule UTP on the sample firms. Equation (1) assumes the residuals are independent and identically distributed, and stock returns are serially independent. Because Smith et al. (1986) suggest that the residuals are not likely to be independent and identically distributed, we correct for possible time-series heteroscedasticity by utilizing a procedure that allows the variance-covariance matrix of the residuals to vary across observations (White 1980).

\section{Cross-Sectional Variation in Stock Price Response}

To investigate whether the impact of Schedule UTP pronouncements is a function of firm characteristics associated with tax aggressiveness (i.e., to test H1a, H2a, H3a), we use the portfolio weighting procedure developed by Sefcik and Thompson (1986) and used extensively in prior literature (e.g., Espahbodi et al. 2002; Li et al. 2008; Donohoe and McGill 2011). This method accounts for cross-sectional heteroscedasticity and cross-correlation of the residuals likely to occur in the presence of common event dates. It also allows us to include information relating to the full covariance matrix of the residuals in the analysis by creating separate portfolios for the characteristics of interest (specifically, each firm's tax aggressiveness characteristic). We then use each portfolio to re-estimate Equation (1) where estimates of $g_{p k}$ reflect the effect of the $p$ th tax aggressiveness proxy on the stock-price reaction to the $k$ th event.

This procedure involves three steps. First, we first create a matrix $F$ that has a column of ones and two columns of firm characteristics of interest, namely UTB and PERMBTD. This matrix is defined as follows:

$$
F=\left[1 X_{2} \ldots X_{p}\right]
$$

where $X_{p}$ is an $N \times 1$ vector of the $p$ th firm characteristic ( $P=2$ and $N$ is the total number of firms used to test H1a, H2a, and H3a).

Second, we create $P=2$ sets of portfolio weights $W$ and calculate the portfolio returns for each day $t\left(w R_{p t}\right)$ for each set as follows:

$$
\begin{aligned}
& W=\left(F^{\prime} F\right)^{-1} F^{\prime}, \\
& w R_{p t}=W_{p}^{\prime} R_{t},
\end{aligned}
$$

where $F$ is an $N \times P$ matrix defined in Equation (2); $w R_{p t}$ is the return for portfolio $p$ on day $t ; R_{t}$ is an $N \times 1$ vector of individual firms' returns on day $t$ ( $N$ is the total number of firms); and $W_{p}{ }^{\prime}$ is a $p$ th row of portfolio weights that are influenced by the $p$ th firm characteristic (a single column of $F$ ). Each of the rows in matrix $W$ represents a set of weights that are used in Equation (4) to compute portfolio returns. Essentially, we create portfolios corresponding to each row, where the first is the intercept and the others have returns influenced by only one firm characteristic (namely, UTB and PERMBTD).

Third, we re-estimate Equation (1) as follows:

$$
w R_{p t}=\alpha_{p}+\beta_{p} R_{m t}+\sum_{k=1}^{K} g_{p k} D_{k t}+e_{p t},
$$

where $w R_{p t}$ is the weighted portfolio returns and the weight is based on the firm's tax aggressiveness measure. The estimates of $g_{p k}$ reflect the effect of the $p$ th tax aggressiveness proxy 
on the stock-price reaction to the $k$ th event. Because we are testing the association between returns and the construct of tax aggressiveness rather than the incremental effect of each measure of tax aggressiveness, we form weighted portfolio returns separately for each measure of tax aggressiveness. This weighting procedure provides an opportunity to evaluate the relative importance of different firm tax aggressiveness measures in explaining the stock price reaction to announcements related to Schedule UTP.

\section{Financial Reporting of UTBs}

To investigate whether the amount of UTBs reported in the financial statements decreased subsequent to the adoption of Schedule UTP, we add a fiscal year indicator variable to the Cazier et al. (2009) model, which includes variables identified in prior research as determinants of tax avoidance and/or tax reserves. Specifically, we estimate the following regression model for all firms with available UTB and control variable data for years 2007 to 2010:

$$
\begin{aligned}
\text { UTB }_{t}= & \alpha_{0}+\alpha_{1} \text { FY2010 }_{t}+\alpha_{2} \text { PTROA }_{t}+\alpha_{3} \text { SIZE }_{t}+\alpha_{4} \text { FORINC }_{t}+\alpha_{5} R \& D_{t}+\alpha_{6} D A_{t} \\
& +\alpha_{7} \text { LEV }_{t}+\alpha_{8} \text { MTB }_{t}+\alpha_{9} \text { COVERAGE }_{t}+\alpha_{10} \text { SALESGR }_{t}+\alpha_{11} \text { CASH ETR }_{t}+\varepsilon_{t},
\end{aligned}
$$

where $U T B$ is the balance of UTBs reported in the financial statements at the end of the fiscal year scaled by lagged total assets. FY2010 is an indicator variable equal to 1 when the fiscal year ended in 2010, and equal to 0 otherwise. H4 predicts a decrease in reported UTBs subsequent to the adoption of Schedule UTP, so we expect a negative coefficient on FY2010, which would indicate a decrease in the level of reported UTBs in 2010.

To control for non-discretionary changes in tax reserves, we include control variables that are based on prior studies of tax avoidance and tax reserves (e.g., Cazier et al. 2009; Wilson 2009; Lisowsky 2010). ${ }^{18} \mathrm{We}$ include PTROA (pre-tax return on assets) and SIZE (total assets) because we expect that large, profitable firms have greater ability and incentive to engage in tax planning that involves significant uncertainty. We include FORINC (foreign sales to total sales) and $R \& D$ because prior research suggests that firms with foreign operations and greater research and development expenditures engage in more tax avoidance than other firms (Wilson 2009). ${ }^{19}$

Because UTBs are liabilities subject to managerial discretion, we also control for financial reporting quality by controlling for discretionary accruals $(D A)$ calculated by the modified Jones model. We control for $L E V$ (leverage) because prior research demonstrates an inverse relation between leverage and aggressive tax planning (Wilson 2009). MTB (market to book ratio) and SALESGR (sales growth) are used to control for growth, because growth firms are subject to greater capital market pressure to meet market expectations and may engage in more aggressive tax planning (e.g., Skinner and Sloan 2002).

COVERAGE (analyst coverage) is the number of analysts following the firm. Analyst coverage is a form of monitoring that could reduce aggressive tax planning (MacDonald 2010). However, greater visibility of the firm may lead to increased tax aggressiveness because increased coverage is usually accompanied by increased pressure on managers to perform (Yu 2008); therefore, we make no prediction about the effect of COVERAGE. ${ }^{20}$ Finally, because firms that avoid more income

18 Cazier et al. (2009) include selling and administrative expenses (SGA) as a control variable. We exclude SGA because approximately 15 percent of our sample firms have missing values for this variable. Our results are similar when we include SGA in Equation (6).

19 Furthermore, Shulman (2011) indicates research and development tax credit and transfer pricing are two of the most common Schedule UTP reportable issues.

20 Prior research is mixed on the effect of analyst coverage and tax aggression. Frank et al. (2009) find a significantly negative relationship between measures of tax avoidance (DTAX and book-tax differences) and sell-side analysts tracking a firm. However, Cazier et al. (2009) do not find within their sample a negative relationship between firms' UTBs and analyst coverage. 
taxes are more likely to require a tax contingency under FIN 48, we include CASH ETR in our model to control for the effects of firm-specific tax-planning activities (Cazier et al. 2009).

FIN 48 requires firms to disclose changes in UTBs related to current-year tax positions, prioryear tax positions, settlements with tax authorities, and statute of limitations expirations. Because Schedule UTP (as eventually adopted) requires reporting only current-year additions to the UTB balance, it is likely that firms will carefully consider additions to reported UTBs. As Cravath, Swaine \& Moore $(2010,2)$ note, the decision to create a reserve for a tax item will place that item "under a spotlight." Therefore, it follows that firms will reduce their reported additions to UTB. To investigate this notion, we expand Equation (6) to examine the additions to UTB (UTBADD) as follows:

$$
\begin{aligned}
& \text { UTBADD } D_{t}=\alpha_{0}+\alpha_{1} \text { FY2010 }_{t}+\alpha_{2} \text { PTROA }_{t}+\alpha_{3} \text { SIZE }_{t}+\alpha_{4} \text { FORINC }_{t}+\alpha_{5} R \& D_{t}+\alpha_{6} \text { DA }_{t} \\
& +\alpha_{7} \text { LEV }_{t}+\alpha_{8} \text { MTB }_{t}+\alpha_{9} \text { COVERAGE }_{t}+\alpha_{10} \text { SALESGR }_{t}+\alpha_{11} \text { CASH ETR }_{t} \\
& +\alpha_{12} U T \text { USSETTLE } E_{t}+\varepsilon_{t} \text {, }
\end{aligned}
$$

where $U T B A D D$ is the amount of current-year additions to UTB disclosed in the UTB reconciliation, scaled by $A S S E T S_{t-1}$, and UTBSETTLE is the amount of current-year settlements disclosed in the UTB reconciliation, also scaled by $\operatorname{ASSETS~}_{t-1}$. Cazier et al. (2009) document a negative relation between UTBSETTLE and UTBADD. They suggest that this is consistent with firms maintaining their tax contingencies as "cookie jar reserves" to facilitate future earnings management. All other variables are as defined in Equation (6). A negative coefficient on FY2010 would indicate that additions to reported UTB were lower in 2010.

\section{EMPIRICAL RESULTS}

\section{Descriptive Statistics for Stock Price Response Sample}

Descriptive statistics for the stock price reaction sample are provided in Panel A of Table 2. Mean reported UTBs are \$54.4 million (UTB [millions]) and represent approximately 1.4 percent of firms' total assets (UTB [scaled]). Mean PERMBTD (0.048) is similar to prior studies (e.g., Frischmann et al. 2008). Panel B of Table 2 presents the industry distribution for the sample of firms used to test H1-H3a. The manufacturing industry, which comprises 43 percent of our sample firms, is the largest industry represented in our sample.

\section{Stock Price Response}

Table 3 presents the results from our tests of H1-H3a. Specifically, Column (1) of Table 3 presents the portfolio cumulative abnormal return (CAR) and robust standard errors (RSE) for our dates of interest, where the CAR is the estimated coefficient $g_{p k}$ from Equation (1) in percentage format (H1, H2, and H3). Columns (2) and (3) present the abnormal results from the estimation of Equation (5) using portfolio weighted returns, where the tax aggressiveness measure is indicated in the column heading. Columns (2) and (3) of Table 3 provide a direct test of whether the returns are associated with tax aggressiveness (H1a, H2a, and H3a).

The results in Column (1) of Table 3 indicate there was a significant negative stock price reaction for our sample of firms around the January 26, 2010 date $(p<0.001)$, which is consistent with H1. The CAR for the January 26, 2010 date was -0.184 percent, which amounts to a $\$ 9.55$ million decline in market value for the average sample firm $(-0.184$ percent $\times \$ 5,191,000$ average market value of equity).

It is important to note that this finding is inconsistent with Edwards et al. (2010), who do not document a significant stock price reaction to Announcement 2010-9. However, their sample is limited to 260 of the S\&P 500 firms, while our sample comprises all firms with assets greater than $\$ 10$ million. When we limit our sample December year-end S\&P 500 firms, we find no significant stock price reaction to the initial proposal of Schedule UTP $(\mathrm{CAR}=0.01, \mathrm{t}=0.27)$, which is 


\section{TABLE 2}

\section{Descriptive Statistics for Stock Price Reaction Sample}

\section{Panel A: Descriptive Statistics}

\begin{tabular}{|c|c|c|c|c|c|c|}
\hline Variable & $\mathbf{n}$ & Mean & Std. Dev. & Q1 & Median & Q3 \\
\hline ASSETS & 3,752 & $8,112.1$ & $26,882.3$ & 188.5 & 780.4 & $3,645.2$ \\
\hline$M V E$ & 3,752 & $5,191.6$ & $14,375.1$ & 187.2 & 756.4 & $2,987.6$ \\
\hline PTROA & 3,752 & 0.052 & 0.188 & 0.006 & 0.059 & 0.126 \\
\hline UTB (millions) & 2,869 & 54.40 & 182.9 & 0.30 & 3.40 & 21.40 \\
\hline UTB (scaled) & 2,869 & 0.014 & 0.024 & 0.001 & 0.005 & 0.016 \\
\hline PERMBTD & 2,627 & 0.048 & 0.101 & 0.004 & 0.021 & 0.059 \\
\hline
\end{tabular}

\section{Panel B: Industry Distribution}

$\frac{\text { SIC Code }}{1-1499}$
$1500-1999$
$2000-3999$
$4000-4999$
$5000-5999$
$6000-6999$
$7000-7999$
$8000-8999$

\begin{tabular}{l} 
Description \\
\hline Agriculture, Forestry, and Mining \\
Construction \\
Manufacturing \\
Transportation and Communication \\
Wholesale \\
Financial Services \\
Business and Personal Service \\
Other Services \\
Total
\end{tabular}

\begin{tabular}{rr} 
Firms & \% of Firms \\
\cline { 3 - 3 } 212 & $6 \%$ \\
42 & $1 \%$ \\
1,606 & $43 \%$ \\
407 & $11 \%$ \\
360 & $10 \%$ \\
471 & $12 \%$ \\
495 & $13 \%$ \\
159 & $4 \%$ \\
\hline 3,752 & $100 \%$
\end{tabular}

This table presents descriptive statistics for the sample used to test the stock price response to the events leading to the adoption of Schedule UTP. Panel A presents descriptive statistics for the stock price reaction sample. Panel B presents the industry distribution of the stock price reaction sample.

See Appendix A for variable definitions and calculations.

consistent with Edwards et al. (2010). This suggests that the news of Schedule UTP was more significant for the smaller firms that are less likely to be currently under audit or subject to audit on a continual basis.

The stock price reaction to Announcement 2010-30 on the April 19, 2010 date is insignificant $(\mathrm{p}<0.3246)$. This result is inconsistent with $\mathrm{H} 2$, suggesting that the draft and instructions to Schedule UTP provided no new information to investors about firms' future tax burdens and/or tax compliance costs. Taken together with our results from tests of H1, this result suggests that investors impounded negative perceptions of Schedule UTP into stock prices at the date of the first announcement of Schedule UTP, which was January 26, 2010.

On the other hand, there is a significant positive stock price reaction around the September 24, 2010 date $(\mathrm{p}<0.001)$. This result suggests that market participants view the relaxed requirements of the final draft of Schedule UTP as positive news, and is consistent with H3. The CAR of 0.139 percent amounts to a $\$ 7.21$ million increase in market value of equity for the average sample firm. In sum, the results in Column (1) of Table 3 provide evidence that investors believed firms would incur significant additional costs as a result of Schedule UTP upon the initial announcement of 


\section{TABLE 3}

\section{Stock Price Reaction to Events Affecting the Adoption of Schedule UTP}

\section{Equally Weighted Portfolio Returns}

(1)

All Firms

CAR

Event Date

January 26,2010

April 19, 2010

September 24, 2010

$-0.184 * * *$

\section{(RSE)}

$(0.0002)$

$-0.017$

(0.0002)

$0.139 * * *$

(0.0002)

3,752
Weighted

Portfolio Returns

\begin{tabular}{cc}
\hline (2) & $(3)$ \\
UTB & PERMBTD \\
CAR & CAR \\
(RSE) & (RSE) \\
-0.143 & -0.224 \\
$(0.0017)$ & $(0.0022)$ \\
-0.278 & $-0.213 * * *$ \\
$(0.0059)$ & $(0.0011)$ \\
$0.402 * *$ & $0.347 *$ \\
$(0.0019)$ & $(0.0020)$ \\
2,869 & 2,627
\end{tabular}

*,**,*** Denote statistical significance at the 90, 95, and 99 percent confidence levels, respectively (two-tailed). This table reports results for tests of the stock price response to the events leading to the adoption of Schedule UTP. Column (1) presents the results of estimating the following equation (Equation (1)) for our sample firms:

$$
R_{p t}=\alpha_{p}+\beta_{p} R_{m t}+\sum_{k=1}^{K} g_{p k} D_{k t}+e_{p t}
$$

The cumulative abnormal portfolio return (CAR) is the estimated coefficient $g_{p k}$ from Equation (1) in percentage format, where $D_{k t}$ is set equal to 1 for the three days surrounding each event of interest identified in Table 1 , and 0 otherwise. We use daily return observations from January 1, 2010 to December 31, 2010.

Columns (2) and (3) present the results of estimating Equation (5), below, for a weighted portfolio of firms:

$$
w R_{p t}=\alpha_{p}+\beta_{p} R_{m t}+\sum_{k=1}^{K} g_{p k} D_{k t}+e_{p t}
$$

where the weight is based on the metric indicated by the column heading and calculated by Equation (4), below, following Sefcik and Thompson (1986):

$$
w R_{p t}=W_{p}^{\prime} R_{i t}, \text { where }: W=\left(F^{\prime} F\right)^{-1} F^{\prime} .
$$

White (1980) standard errors are shown in parentheses below the coefficients.

See Appendix A for variable definitions and calculations.

Schedule UTP on January 26, 2010, but that investors responded favorably to the final draft of Schedule UTP in which many of the controversial provisions of the proposal were relaxed. ${ }^{21}$

\section{Cross-Sectional Variation in Stock Price Response}

To examine whether the stock price response to the news about Schedule UTP varies as a function of tax aggressiveness, we use the portfolio weighting procedure described in Equation (4). The reported cumulative abnormal portfolio returns are the coefficient estimates (in percentage format) for each event indicator variable $\left(g_{p k}\right)$ in Equation (5). A positive (negative) and significant

21 As an additional analysis, we remove all firms with less than $\$ 100$ million in assets, that is, those firms that were not required to file Schedule UTP as a result of the relaxed provisions of Announcement 2010-75. We find that the positive stock price reaction for firms with assets greater than $\$ 100$ million persists and our results are not driven by the positive reaction to firms with less than $\$ 100$ million no longer being subject to Schedule UTP. 
association with the tax aggression measure indicates the more (less) tax aggressive the firm, the more positive (negative) the market response.

Column (2) of Table 3 reports the results from Equation (5) using the level of reported UTBs as our tax aggressiveness measure. Our results indicate that there was a negative association between stock returns and level of reported UTBs around the first two event dates, but this association is not statistically significant, which is inconsistent with H1a and H2a. However, we document a significant positive association between the level of reported UTBs and stock returns on the September 24 date, which is consistent with H3a. Additionally, Column (3) of Table 3 presents the results from Equation (5) using PERMBTD as our tax aggressiveness measure. Once again, the association between stock returns and PERMBTD is negative on January 26, but not statistically significant. However, we do find that PERMBTD is negatively related to stock price reaction to Announcement 2010-30 on April 19 ( $\mathrm{p}<0.001$ ), which is consistent with H2a. Column (3) also reveals that the level of PERMBTD is significantly positively related to Announcement 2010-75 on September 24, 2010 ( $\mathrm{p}<0.001$ ), which is consistent with H3a.

Overall, Table 3 suggests that at the initial announcement of Schedule UTP (January 26, 2010), investors believed that Schedule UTP would increase firms' future tax burdens and tax-compliance costs, which is consistent with H1. Additionally, investors responded favorably to the relaxed provisions of Schedule UTP that were announced on September 24, 2010, which is consistent with H3. We find no significant association between stock price response and the release of the draft Schedule UTP on April 19, 2010. The results also indicate that the stock price reaction to the relaxed provisions of Schedule UTP is positively associated with both measures of tax aggressiveness, but we find little support for our expectations that investors view Schedule UTP to be particularly costly for firms with higher levels of reported UTBs and firms with higher permanent book-tax differences. These findings lead to our fourth hypothesis that firms respond to Schedule UTP by decreasing their level of reported UTBs.

\section{Descriptive Statistics for UTB Reporting Sample}

Descriptive statistics for the UTB reporting sample are provided in Panel A of Table 4. Mean reported UTB (UTB millions) for our sample firms is $\$ 77.8$ million, which is approximately 1.3 percent of lagged assets $(U T B)$. Our sample firms had additions to UTB (UTBADD) of about $\$ 10.0$ million (per year), on average, over the time period 2007 to 2010.

Panel B of Table 4 presents the Pearson correlations among regression variables UTB and $U T B A D D$ for the UTB reporting sample. The correlation between FY2010 and both UTB and $U T B A D D$ is negative $(-0.01$ and -0.05$)$, but is only significant at the 0.05 or better level for $U T B A D D$, which suggests that additions to UTB were lower in 2010.

Panel $\mathrm{C}$ of Table 4 presents the industry distribution for the sample of firms used to test $\mathrm{H} 4$. Manufacturing firms, wholesale, and service firms comprise 46 percent, 13 percent, and 13 percent of our sample firms, respectively.

\section{Financial Reporting of UTBs}

Figure 1 graphs the average reported UTBs (in \$ millions) by year for our sample firms. UTBs increased from $\$ 68.5$ million in 2006 to $\$ 81.7$ million in 2009. In 2010, the reported UTBs decreased to $\$ 79.3$ million. It is important to note that while a decrease in reported UTBs of just over \$2 million may not appear significant, reported UTBs had increased, on average 6 percent per year from 2006 to 2009. Applying this average increase to the 2009 balance, we would expect reported UTBs in 2010 to be about $\$ 86.6$ million. However, reported UTBs actually decreased by 3 percent in 2010 to $\$ 79.3$ million. Our final set of tests examines the significance of this decrease in UTBs reported in the financial statements following the release of Schedule UTP. 
TABLE 4

Descriptive Statistics for UTB Reporting Sample

Panel A: Descriptive Statistics for UTB Reporting Sample

\begin{tabular}{|c|c|c|c|c|c|c|}
\hline Variable & $\mathbf{n}$ & Mean & Std. Dev. & Q1 & Median & Q3 \\
\hline UTB (millions) & 5,068 & 77.846 & 234.462 & 1.798 & 7.816 & 40.000 \\
\hline$U T B A D D$ (millions) & 5,068 & 9.995 & 33.762 & 0.000 & 0.600 & 4.129 \\
\hline$U T B$ & 5,068 & 0.013 & 0.018 & 0.002 & 0.007 & 0.017 \\
\hline$U T B A D D$ & 5,068 & 0.002 & 0.003 & 0.000 & 0.001 & 0.002 \\
\hline UTBSETTLE & 5,068 & -0.001 & 0.003 & 0.000 & 0.000 & 0.000 \\
\hline FY2010 & 5,068 & 0.250 & 0.433 & 0.000 & 0.000 & 1.000 \\
\hline PTROA & 5,068 & 0.061 & 0.131 & 0.004 & 0.062 & 0.127 \\
\hline SIZE & 5,068 & 7.363 & 1.648 & 6.121 & 7.157 & 8.443 \\
\hline FORINC & 5,068 & 0.377 & 0.785 & 0.000 & 0.052 & 0.512 \\
\hline$R \& D$ & 5,068 & 0.029 & 0.054 & 0.000 & 0.000 & 0.032 \\
\hline$D A$ & 5,068 & -0.075 & 2.761 & -0.108 & 0.010 & 0.124 \\
\hline$L E V$ & 5,068 & 0.250 & 0.255 & 0.038 & 0.198 & 0.369 \\
\hline MTB & 5,068 & 2.323 & 3.342 & 1.060 & 1.731 & 2.840 \\
\hline COVERAGE & 5,068 & 7.785 & 6.824 & 2.000 & 6.000 & 12.000 \\
\hline SALESGR & 5,068 & 0.109 & 0.231 & -0.004 & 0.069 & 0.164 \\
\hline CASH ETR & 5,068 & 0.246 & 0.199 & 0.106 & 0.237 & 0.332 \\
\hline
\end{tabular}

\section{Panel B: Pearson Correlations}

UTB- UTB- FY- PT- FOR-

COVER-SALES-

$U T B A D D$
0.60

UTBSETTLE $-\mathbf{0 . 1 6}-\mathbf{0 . 1 2}$

$\begin{array}{lll}F Y 2010 & -0.01-\mathbf{0 . 0 5} & -0.00\end{array}$

$\begin{array}{lrlll}P T R O A & \mathbf{0 . 0 5} & \mathbf{0 . 1 4} & -0.02 & \mathbf{0 . 0 7}\end{array}$

$\begin{array}{llllll}\text { SIZE } & -0.01 & \mathbf{0 . 0 3} & -\mathbf{0 . 0 7} & 0.02 & \mathbf{0 . 0 6}\end{array}$

$\begin{array}{lllllll}\text { FORINC } & \mathbf{0 . 1 4} & \mathbf{0 . 0 9} & -\mathbf{0 . 0 5} & -0.01 & -0.04 & \mathbf{0 . 0 6}\end{array}$

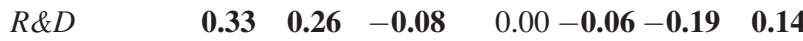

$D A \quad-0.01-0.00 \quad 0.00 \quad-0.02-0.01-0.00 \quad 0.00 \quad 0.02$

$\begin{array}{llllllll}L E V & -\mathbf{0 . 0 5}-\mathbf{0 . 0 5} & \mathbf{0 . 0 3} & -0.00-\mathbf{0 . 1 1} & \mathbf{0 . 2 1} & -0.01-\mathbf{0 . 2 2} & \mathbf{0 . 0 3}\end{array}$

$\begin{array}{llllllllll}M T B & \mathbf{0 . 0 5} & \mathbf{0 . 0 8} & -0.02 & -0.01 & \mathbf{0 . 2 3} & 0.01-0.01 & \mathbf{0 . 1 2} & -0.01-\mathbf{0 . 0 5}\end{array}$

$\begin{array}{llllllllllll}\text { COVERAGE } & \mathbf{0 . 0 7} & \mathbf{0 . 1 1} & -\mathbf{0 . 0 5} & \mathbf{0 . 0 8} & \mathbf{0 . 2 3} & \mathbf{0 . 5 1}-0.01 & \mathbf{0 . 0 6} & \mathbf{0 . 0 4}-\mathbf{0 . 0 5} & \mathbf{0 . 1 7}\end{array}$

$\begin{array}{lllllllllllll}S A L E S G R & -\mathbf{0 . 0 6} & \mathbf{0 . 0 3} & \mathbf{0 . 0 8} & -\mathbf{0 . 1 3} & \mathbf{0 . 1 3}-0.01 & 0.00 & \mathbf{0 . 1 2} & 0.02 & \mathbf{0 . 1 1} & \mathbf{0 . 1 1} & \mathbf{0 . 0 8}\end{array}$

$\begin{array}{llllllllll}C A S H & E T R & -\mathbf{0 . 0 9}-\mathbf{0 . 0 6} & -\mathbf{0 . 0 4} & 0.01 & \mathbf{0 . 0 6}-0.00 & 0.02-\mathbf{0 . 1 8}-0.00-\mathbf{0 . 0 8}-\mathbf{0 . 0 3} & -\mathbf{0 . 0 3} & -\mathbf{0 . 1 3}\end{array}$

Panel C: Industry Distribution

\begin{tabular}{|c|c|c|c|c|}
\hline SIC Code & Description & Obs. & Firms & $\%$ of Firms \\
\hline $1-1499$ & Agriculture, Forestry, and Mining & 256 & 63 & $5 \%$ \\
\hline 1500-1999 & Construction & 52 & 13 & $1 \%$ \\
\hline 2000-3999 & Manufacturing & 2,308 & 577 & $46 \%$ \\
\hline $4000-4999$ & Transportation and Communication & 448 & 112 & $9 \%$ \\
\hline $5000-5999$ & Wholesale & 648 & 162 & $13 \%$ \\
\hline $6000-6999$ & Financial Services & 476 & 119 & $9 \%$ \\
\hline 7000-7999 & Business and Personal Service & 656 & 164 & $13 \%$ \\
\hline \multirow[t]{2}{*}{$8000-8999$} & Other Services & 224 & 56 & $4 \%$ \\
\hline & Total & 5,068 & 1,266 & $100 \%$ \\
\hline
\end{tabular}




\section{TABLE 4 (continued)}

This table presents descriptive statistics for the sample used to test for a decrease in reported UTBs following the promulgation of Schedule UTP. Panel A presents descriptive statistics for the variables used in multivariate analysis for the UTB financial reporting sample. Panel B presents the correlations among variables used in the regression analysis where bold denotes significance at $\mathrm{p}<0.05$ (two-tailed). Panel $\mathrm{C}$ presents the industry distribution for the UTB reporting sample. See Appendix A for variable definitions and calculations.

Table 5 presents the results from our tests of H4. Column (1) of Table 5 shows the results from the estimation of Equation (6), where we regress UTB on FY2010 and determinants of UTBs. The coefficient on FY2010 is negative and significant at the 0.01 level, which suggests that after controlling for firm characteristics associated with UTBs from prior research (Cazier et al. 2009; Lisowsky et al. 2011), UTBs were significantly lower in $2010 .^{22}$ These results provide evidence that the level of reported UTBs decreased subsequent to the adoption of Schedule UTP.

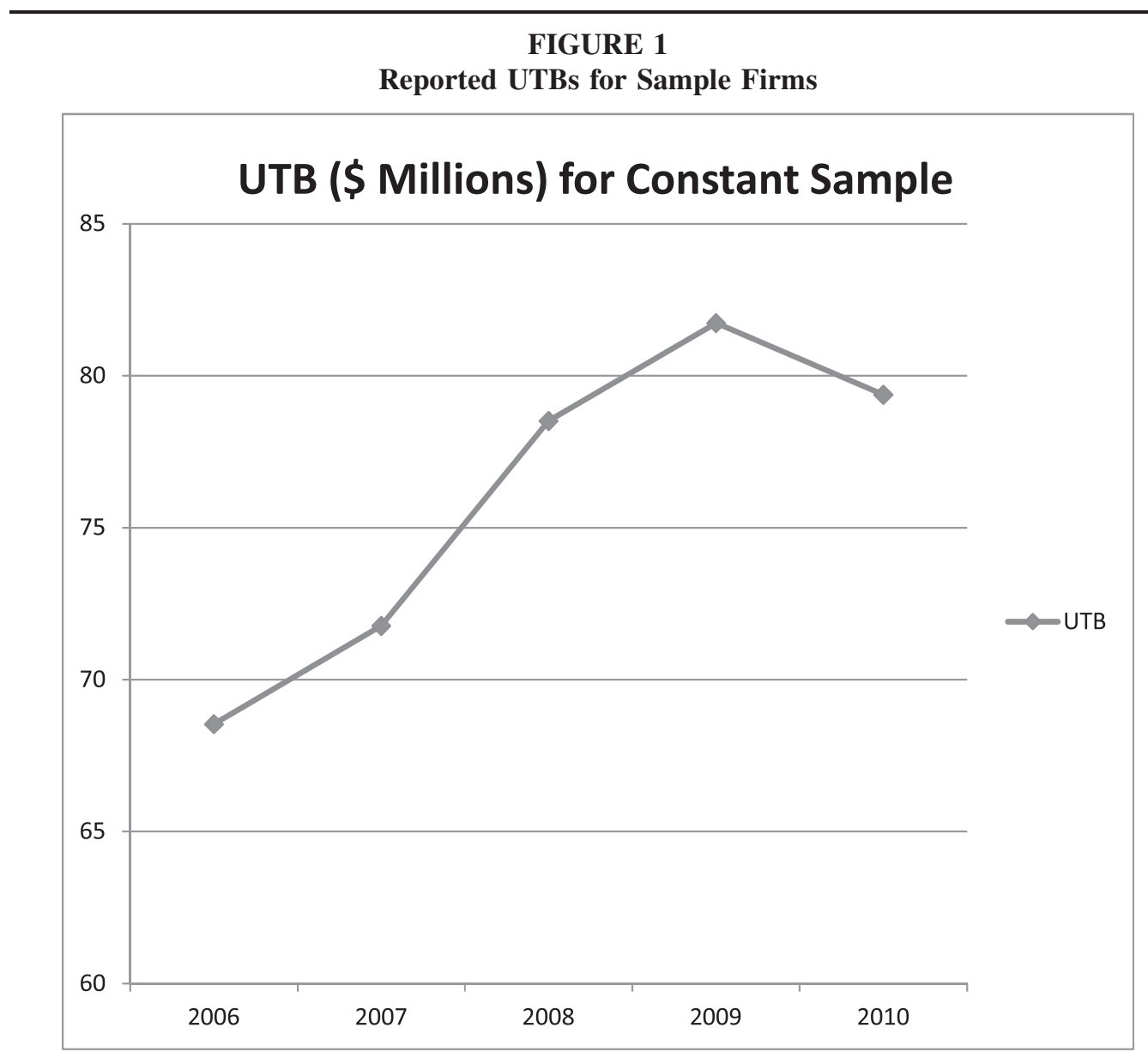

This figure plots mean values of reported UTBs (unscaled) for our financial reporting sample $(1,267$ firms) for the period 2006-2010. 


\section{TABLE 5}

OLS Regressions Investigating Levels of UTBs and Additions to UTBs around the Release of Schedule UTP

\begin{tabular}{|c|c|c|}
\hline & $\begin{array}{l}(1) \\
\text { UTB }\end{array}$ & $\begin{array}{c}(2) \\
\text { UTBADD }\end{array}$ \\
\hline Intercept & $\begin{array}{c}-0.00775^{* * *} \\
(0.00233)\end{array}$ & $\begin{array}{c}0.00028 \\
(0.00028)\end{array}$ \\
\hline FY2010 & $\begin{array}{c}-0.00152 * * * \\
(0.00032)\end{array}$ & $\begin{array}{c}-0.00050^{* * *} \\
(0.00007)\end{array}$ \\
\hline PTROA & $\begin{array}{l}0.01230^{* * * *} \\
(0.00395)\end{array}$ & $\begin{array}{l}0.00370^{* * * *} \\
(0.00063)\end{array}$ \\
\hline SIZE & $\begin{array}{c}0.00024 \\
(0.00031)\end{array}$ & $\begin{array}{c}0.00007^{*} \\
(0.00004)\end{array}$ \\
\hline FORINC & $\begin{array}{l}0.00231 * * * \\
(0.00044)\end{array}$ & $\begin{array}{l}0.00022^{* * *} \\
(0.00007)\end{array}$ \\
\hline$R \& D$ & $\begin{array}{l}0.11243^{* * *} \\
(0.01178)\end{array}$ & $\begin{array}{l}0.01529 * * * \\
(0.00177)\end{array}$ \\
\hline$D A$ & $\begin{array}{c}-0.00014 \\
(0.00009)\end{array}$ & $\begin{array}{c}-0.00001 \\
(0.00002)\end{array}$ \\
\hline$L E V$ & $\begin{array}{c}0.00299 \\
(0.00211)\end{array}$ & $\begin{array}{c}0.00028 \\
(0.00032)\end{array}$ \\
\hline$M T B$ & $\begin{array}{c}-0.00003 \\
(0.00014)\end{array}$ & $\begin{array}{c}0.00001 \\
(0.00002)\end{array}$ \\
\hline COVERAGE & $\begin{array}{c}0.00008 \\
(0.00007)\end{array}$ & $\begin{array}{c}0.00002^{*} \\
(0.00001)\end{array}$ \\
\hline SALESGR & $\begin{array}{c}-0.00978^{* * * *} \\
(0.00168)\end{array}$ & $\begin{array}{c}-0.00042 \\
(0.00032)\end{array}$ \\
\hline CASH ETR & $\begin{array}{c}-0.00396 * * \\
(0.00191)\end{array}$ & $\begin{array}{c}-0.00008 \\
(0.00026)\end{array}$ \\
\hline SETTLE & & $\begin{array}{c}-0.11187 * * * \\
(0.02543)\end{array}$ \\
\hline $\begin{array}{l}\text { Obs. } \\
\mathrm{R}^{2}\end{array}$ & $\begin{array}{c}5,068 \\
0.1396\end{array}$ & $\begin{array}{c}5,068 \\
0.1126\end{array}$ \\
\hline
\end{tabular}

$*, * *, * * *$ Denote statistical significance at the 90,95 , and 99 percent confidence levels, respectively; tests are one-tailed for variables with a predicted sign, and two-tailed otherwise.

Column (1) presents the results of estimating the following equation (Equation (6)) for our sample firms with data available for the years 2007-2010:

$$
\begin{aligned}
\text { UTB }_{t}= & \alpha_{0}+\alpha_{1} \text { FY2010 }_{t}+\alpha_{2} \text { PTROA }_{t}+\alpha_{3} \text { SIZE }_{t}+\alpha_{4} \text { FORINC }_{t}+\alpha_{5} R \& D_{t}+\alpha_{6} D_{t}+\alpha_{7} L_{E V_{t}}+\alpha_{8} \text { MTB }_{t} \\
& +\alpha_{9} \text { COVERAGE }_{t}+\alpha_{10} \text { SALESGR }_{t}+\alpha_{11} \text { CASH ETR }_{t}+\varepsilon_{t} .
\end{aligned}
$$

Column (2) presents the results of estimating the following equation (Equation (7)) for our sample firms with data available for the years 2007-2010:

$$
\begin{aligned}
& U T B A D D_{t}=\alpha_{0}+\alpha_{1} \text { FY2010 }_{t}+\alpha_{2} \text { PTROA }_{t}+\alpha_{3} \text { SIZE }_{t}+\alpha_{4} \text { FORINC }_{t}+\alpha_{5} R \& D_{t}+\alpha_{6} D A_{t}+\alpha_{7} L E V_{t}+\alpha_{8} \text { MTB }_{t} \\
& +\alpha_{9} \text { COVERAGE }_{t}+\alpha_{10} \text { SALESGR }_{t}+\alpha_{11} \text { CASH ETR }_{t}+\alpha_{12} \text { UTBSETTLE }_{t}+\varepsilon_{t} .
\end{aligned}
$$

White (1980) standard errors are shown in parentheses below the coefficients.

See Appendix A for variable definitions and calculations. 
We also note a significant association between $R \& D$ and $U T B$, which is consistent with recent information about Schedule UTP that indicates research tax credits are the most common position reported on Schedule UTP (Shulman 2011). The positive association between PTROA and FORINC and $U T B$ indicates that more profitable firms and firms with foreign operations are more likely to report uncertain tax positions. We also document a negative association between CASH ETR and $U T B$, which indicates that firms that engage in more tax planning/tax avoidance have higher levels of reported UTBs (lower CASH ETR indicates higher tax avoidance).

\section{Additions to UTB}

Column (2) of Table 5 provides results from Equation (7). In this model, we regress UTBADD on FY2010 and determinants of additions to UTB identified in prior research (Cazier et al. 2009). The coefficient on FY2010 is negative and significant $(\mathrm{p}<0.001)$. This suggests that additions to reported current-year UTBs were significantly lower in 2010. This result supports the notion that firms carefully considered uncertain tax positions taken in 2010 as a result of the potential increased scrutiny from the IRS.

We note similar significant associations between UTBADD and PTROA, FORINC, and R\&D as we did in Equation (6). There is also a negative association between settlements of UTB (UTBSETTLE) and UTBADD.

\section{Changes in UTBs}

To ensure that our results are attributable to a change in reported UTBs, and not to changes in the determinants of reported UTBs, we re-estimate Equation (6) using the change in UTB (UTBCHANGE) as the dependent variable. We define UTBCHANGE as the ending balance of UTBs reported in the financial statement footnotes minus the beginning balance of UTBs scaled by ASSETS $_{t-1}$. We regress UTBCHANGE on FY2010 and changes in the determinants of reported UTBs as follows: $:^{23}$

$$
\begin{aligned}
\text { UTBCHANGE }_{t}= & \alpha_{0}+\alpha_{1} \text { FY2010 }_{t}+\alpha_{2} \Delta \text { PTROA }_{t}+\alpha_{3} \Delta \text { SIZE }_{t}+\alpha_{4} \Delta \text { FORINC }_{t}+\alpha_{5} \Delta R \& D_{t} \\
& +\alpha_{6} \Delta D A_{t}+\alpha_{7} \Delta L E V_{t}+\alpha_{8} \Delta M T B_{t}+\alpha_{9} \Delta \text { COVERAGE }_{t}+\alpha_{10} \Delta \text { SALESGR }_{t} \\
& +\alpha_{11} \Delta C A S H \text { ETR }_{t}+\varepsilon_{t} .
\end{aligned}
$$

Table 6 shows the results from the estimation of Equation (8), where we regress UTBCHANGE on FY2010 and changes in the determinants of UTBs. The coefficient on FY2010 is negative and significant at the 0.01 level, which suggests that after controlling for changes in firm characteristics associated with UTBs from prior research (i.e., Cazier et al. 2009), the decrease in reported UTBs in 2010 is significant at the 0.01 level. These results provide evidence that the change in reported UTBs subsequent to the adoption of Schedule UTP is not attributable to changes in other firm characteristics associated with reported UTBs.

\section{Supplemental Analyses}

As is the case with any market event study, there is the possibility that significant economic events occur in the estimation and event windows that confound our results. We have attempted to alleviate these concerns through our research design, and through comprehensive search of news

22 We only include an indicator variable for 2010 because we are interested in the effect in 2010 versus all other years. However, when we include year indicators for the other years, the coefficients on all year indicators except for 2010 are insignificant, which provides assurance that our year indicator is not capturing other year-specific events.

23 Changes in the determinants of reported UTBs are calculated as ending balance of the variable minus prior-year ending balance of the variable. 
TABLE 6

OLS Regressions Investigating the Change in UTBs Around the Release of Schedule UTP

\begin{tabular}{|c|c|}
\hline & UTBCHANGE \\
\hline Intercept & $\begin{array}{c}0.00017 \\
(0.00011)\end{array}$ \\
\hline FY2010 & $\begin{array}{c}-0.00111^{* * * *} \\
(0.00020)\end{array}$ \\
\hline$\triangle P T R O A$ & $\begin{array}{c}-0.00245^{* * * *} \\
(0.00088)\end{array}$ \\
\hline$\triangle S I Z E$ & $\begin{array}{l}0.00537 * * * \\
(0.00055)\end{array}$ \\
\hline$\triangle F O R I N C$ & $\begin{array}{c}0.00001 \\
(0.00006)\end{array}$ \\
\hline$\Delta R \& D$ & $\begin{array}{c}-0.00349 \\
(0.00722)\end{array}$ \\
\hline$\triangle D A$ & $\begin{array}{c}0.00001 \\
(0.00003)\end{array}$ \\
\hline$\triangle L E V$ & $\begin{array}{c}-0.00061 \\
(0.00071)\end{array}$ \\
\hline$\triangle M T B$ & $\begin{array}{c}0.00000 \\
(0.00002)\end{array}$ \\
\hline$\triangle C O V E R A G E$ & $\begin{array}{c}0.00003 \\
(0.00003)\end{array}$ \\
\hline$\triangle S A L E S G R$ & $\begin{array}{c}-0.00096 \\
(0.00068)\end{array}$ \\
\hline$\triangle C A S H E T R$ & $\begin{array}{r}-0.00024 \\
(0.00019)\end{array}$ \\
\hline $\begin{array}{l}\text { Obs. } \\
\mathrm{R}^{2}\end{array}$ & $\begin{array}{c}5,068 \\
0.0397\end{array}$ \\
\hline
\end{tabular}

*,**,*** Denote statistical significance at the 90, 95, and 99 percent confidence levels, respectively; tests are one-tailed for variables with a predicted sign, and two-tailed otherwise.

This table presents the results of estimating the following equation (Equation (8)) for our sample firms with data available for the years 2007-2010:

$$
\begin{aligned}
\text { UTBCHANGE }_{t}= & \alpha_{0}+\alpha_{1} \Delta F Y 2010_{t}+\alpha_{2} \Delta \text { PTROA }_{t}+\alpha_{3} \Delta \text { SIZE }_{t}+\alpha_{4} \Delta F O R I N C_{t}+\alpha_{5} \Delta R \& D_{t}+\alpha_{6} \Delta D A_{t} \\
& +\alpha_{7} \Delta L E V_{t}+\alpha_{8} \Delta M T B_{t}+\alpha_{9} \Delta C O V E R A G E_{t}+\alpha_{10} \Delta \text { SALESGR }_{t}+\alpha_{11} \Delta C A S H \text { ETR }_{t}+\varepsilon_{t} .
\end{aligned}
$$

White (1980) standard errors are shown in parentheses below the coefficients.

See Appendix A for variable definitions and calculations.

reports and the IRS website for additional dates where information about Schedule UTP was announced. While we found no news items that would systematically affect our sample of firms or a specific industry in our sample, we acknowledge that 2010 was a tumultuous year for the financial services industry. To address the possibility that financial firms drive the results in our study, we reestimate our stock price reaction and financial reporting analyses after removing firms in the financial industries (SIC 6000-6999). Our results are not sensitive to the exclusion of financial firms.

With a large sample of firms for our stock price response analysis, we expect any effects of earnings announcements to randomize away. However, to eliminate the effect of any earnings announcements during our dates of observation, we eliminate all firms that announced earnings in the three days prior to or after one of our dates of observation. Our results using this sample are 
similar to our primary results. This provides further assurance that our results are attributable to the release of news about Schedule UTP.

\section{SUMMARY AND CONCLUSIONS}

In 2010, the IRS announced plans to adopt a new schedule (Schedule UTP) requiring firms to disclose uncertain tax positions to the IRS. Former IRS Commissioner Lawrence Gibbs has called Schedule UTP "the biggest change in tax administration in the last 50 years" (Harvey 2011). The proposed reporting requirements of Schedule UTP could significantly increase costs to firms. We provide evidence that investors believe Schedule UTP will increase costs to firms by documenting a significant negative stock price reaction to the original announcement of Schedule UTP. We find mixed evidence that investors believe that the costs will be higher for those firms that take more aggressive tax positions. However, we find that investors reacted favorably to the final draft of Schedule UTP, in which many of the more controversial provisions of the original pronouncement were relaxed. In addition, we find that this positive reaction is significantly positively associated with the tax aggressiveness of our sample firms.

Furthermore, we find that the firms decreased their reported UTBs in 2010, the first year after Schedule UTP was adopted. This decrease is significant even after controlling for changes in other determinants of UTBs. We provide evidence that the additions to UTBs were significantly lower in 2010, which suggests that firms recorded fewer UTBs subsequent to the announcement of Schedule UTP. Taken together, these findings suggest that Schedule UTP had a direct effect on firms' financial reporting decisions. This is consistent with recent reports about the initial filings of Schedule UTP (cf. Shulman 2011).

Schedule UTP builds upon the requirements of FIN 48. FIN 48 raised concerns that the new financial statement disclosure requirements could lead to increased tax costs for firms by providing a "roadmap" for the IRS to more effectively identify and audit uncertain tax positions. Despite these concerns, Frischmann et al. (2008) do not observe a significant negative stock price reaction around any of the key pronouncements leading to the adoption of FIN 48. Additionally, they find little evidence that stock returns around key pronouncement dates vary with measures of tax aggressiveness. Our findings suggest that both investors and managers view Schedule UTP (especially in its early proposed form) as a roadmap that will increase tax burdens on firms. We also find that management responded to the adoption of Schedule UTP by reducing the level of UTBs reported in the financial statements. Whether this change is a result of firms taking less uncertain tax positions or simply reporting fewer uncertain tax positions is an issue for future research.

These findings should be of interest to academics because of the importance of Schedule UTP and how Schedule UTP fits into the IRS's goal to increase corporate tax transparency. These findings should also be of interest to IRS officials and regulators, because Schedule UTP was intended to reduce the tax gap. Additionally, our findings should be of interest to other tax authorities that are considering adopting a version of Schedule UTP. For example, Australia is in the process of adopting its own version of Schedule UTP (Australia's version is referred to as Schedule RTP), and certain state tax administrators in the United States are also considering adopting a version of Schedule UTP (specifically, California and Alabama). Finally, because there is a phase-in based on asset size, future research can examine the specific outcomes for firms that are faced with the requirements of Schedule UTP as these phase-ins come to fruition.

\section{REFERENCES}

Alston and Bird LLP. 2010. IRS' Schedule of Uncertain Tax Positions raises concerns for preserving privilege. Available at: http://www.alston.com/Files/Publication/5f26db66-506c-4e19-856b4807bfb5ef9a/Presentation/PublicationAttachment/845a106e-96ff-4102-8a01-4a8726d6c688/ DomTax0510.pdf 
Blouin, J., C. Gleason, L. Mills, and S. Sikes. 2010. Pre-empting disclosure? Firms' decisions prior to FIN 48. The Accounting Review 85: 791-815.

Boynton, C., and L. Mills. 2004. The evolving Schedule M-3: A new era of corporate show and tell? National Tax Journal 57 (3): 757-772.

Cazier, R., S. Rego, X. Tian, and R. Wilson. 2009. Early Evidence on the Determinants of Unrecognized Tax Benefits. Working paper, The University of Iowa.

Chen, K.-P., and C. Chu. 2005. Internal control versus external manipulation: A model of corporate income tax evasion. RAND Journal of Economics 36 (1): 151-164.

Cravath, Swaine \& Moore LLP. 2010. IRS proposes detailed disclosures of financial statement tax reserves. Available at: http://www.cravath.com/files/Uploads/Documents/Publications/3195026_1.pdf

Desai, M. 2003. The divergence between book and tax income. Tax Policy and the Economy 17 (1): 169-206.

Donohoe, M. P., and G. A. McGill. 2011. The effects of increased book-tax difference tax return disclosures on firm valuation and behavior. Journal of the American Taxation Association 33 (2): 35-65.

Dunbar, A., and N. Massel. 2011. The Economic Consequences of Increased IRS Reporting Requirements. Working paper, University of Connecticut.

Edwards, A., A. Koester, and T. Shevlin. 2010. Examining investor reaction to IRS Announcement 2010-9. Tax Notes 90 (9): 669-674.

Espahbodi, H., P. Espahbodi, Z. Rezaee, and H. Tehranian. 2002. Stock price reaction and value relevance of recognition versus disclosure: The case of stock-based compensation. Journal of Accounting and Economics 33: 343-373.

Fama, E., and K. French. 1993. Common risk factors in the returns on stocks and bonds. Journal of Financial Economics 33: 3-56.

Frank, M. M., L. J. Lynch, and S. O. Rego. 2009. Tax reporting aggressiveness and its relation to aggressive financial reporting. The Accounting Review 84 (2): 467-496.

Frischmann, P. J., T. Shevlin, and R. Wilson. 2008. Economic consequences of increasing the conformity in accounting for uncertain tax benefits. Journal of Accounting and Economics 46: 261-278.

Graham, J. R., and A. L. Tucker. 2006. Tax shelters and corporate debt policy. Journal of Financial Economics 81 (3): 563-594.

Hanlon, M., and S. Heitzman. 2010. A review of tax research. Journal of Accounting and Economics 50 (23):127-178.

Harvey, J. R. 2011. Schedule UTP: Views of a Former Tax Adviser and Administrator. Working paper, Villanova University School of Law.

Heltzer, W. 2009. Conservatism and book tax differences. Journal of Accounting, Auditing and Finance 24: $469-504$.

Internal Revenue Service (IRS). 2010a. Announcement 2010-30: Draft schedule and instructions for uncertain tax positions proposal. Available at: http://www.irs.gov/pub/irs-drop/a-10-30.pdf

Internal Revenue Service (IRS). 2010b. Announcement 2010-9: Uncertain tax positions-Policy of restraint. Available at: http://www.irs.gov/irb/2010-07_IRB/ar08.html

Internal Revenue Service (IRS). 2010c. Announcement 2010-75: Reporting of uncertain tax positions. Available at: http://www.irs.gov/irb/2010-41_IRB/ar11.html

Internal Revenue Service (IRS). 2010d. Announcement 2010-76: Requests for documents provided to independent auditors, policy of restraint and uncertain tax positions. October 12, 2010. Available at: http://www.irs.gov/irb/2010-41_IRB/ar12.html

KPMG. 2010. Disclosing uncertain tax positions to the Internal Revenue Service-A conversation with the chief counsel of the IRS. Available at: http://www.kpmginstitutes.com/tax-governance-institute/ events/expanded-tax-uncertainties-disclosures-irs-tax-counsel.aspx

Leone, M. 2010. IRS offers olive branch to business. Available at: http://www.cfo.com/printable/article. $\mathrm{cfm} / 14526522$

Li, H., M. Pincus, and S. Rego. 2008. Market reaction to events surrounding the Sarbanes-Oxley Act of 2002 and earnings management. Journal of Law and Economics 51 (1): 111-134.

Lisowsky, P. 2010. Seeking shelter: Empirically modeling tax shelters using financial statement information. The Accounting Review 85 (5): 1693-1720. 
Lisowsky, P., L. Robinson, and A. Schmidt. 2011. Do Publicly Disclosed Tax Reserves Tell Us About Privately Disclosed Tax Shelter Activity? Working paper, University of Illinois at UrbanaChampaign, Dartmouth University, and North Carolina State University.

MacDonald, J. L. 2010. Are Tax and Non-Tax Factors Associated with FIN 48 Disclosures? Working paper, Texas A\&M University.

McGill, G., and E. Outslay. 2004. Lost in translation: Detecting tax shelter activity in financial statements. National Tax Journal 57: 739-756.

Miller and Chevalier. 2010. Comments on Announcement 2010-9 and draft Schedule UTP and instructions. Available at: http://www.millerchevalier.com/Publications/MillerChevalierPublications?find=34207

Mills, L., and G. Plesko. 2003. Bridging the reporting gap: A proposal for more informative reconciling of book and tax income. National Tax Journal 56: 865-893.

Schipper, K., and R. Thompson. 1983. The impact of merger-related regulation on the shareholders of acquiring firms. Journal of Accounting Research 21: 184-221.

Sefcik, S., and R. Thompson. 1986. An approach to statistical inferences in cross-sectional models with security abnormal returns as dependent variables. Journal of Accounting Research 24: 316-334.

Shevlin, T. 2002. Commentary: Corporate tax shelters and book-tax differences. Tax Law Review 55: 427-443.

Shulman, D. 2010. Prepared remarks of Commissioner of Internal Revenue Douglas Shulman, New York State Bar Association Taxation Section Annual Meeting. Available at: http://www.us.kpmg.com/ microsite/taxnewsflash/2010/Jan/Shulman_Jan26.pdf

Shulman, D. 2011. Prepared remarks of IRS Commissioner Doug Shulman at the AICPA Fall Meeting in Washington, D.C., Nov. 8, 2011. Available at: http://www.irs.gov/uac/Prepared-Remarks-of-IRSCommissioner-Doug-Shulman-at-the-AICPA-Fall-Meeting-in-Washington,-D.C.,-on-Nov.-8,-2011

Sidley and Austin LLP. 2011. New IRS Schedule UTP tax controversy update. Available at: http://www. sidley.com/SidleyUpdates/Detail.aspx?news $=4568$

Skinner, D., and R. Sloan. 2002. Earnings surprises, growth expectations, and stock returns, or don't let an earnings torpedo sink your portfolio. Review of Accounting Studies 7: 289-312.

Slemrod, J. 2004. The economics of corporate tax selfishness. National Tax Journal 57 (4): 877-899.

Smith, R. T., M. Bradley, and G. Jarrell. 1986. Studying firm-specific effects of regulation with stock market data: An application to oil price regulation. Rand Journal of Economics 17 (4): 467-489.

Tax Executives Institute (TEI). 2010. TEI resource page on IRS Announcement 2010-9-Schedule UTP. Available at: http://www.tei.org/news/Pages/TEIResourcePageonIRSAnnouncement2010-09.aspx

White, H. 1980. A heteroscedasticity-consistent covariance matrix estimator and a direct test for heteroscedasticity. Econometrica 48: 817-838.

Wilson, R. 2009. An examination of corporate tax shelter participants. The Accounting Review 84 (3): $969-$ 999.

Yu, F. 2008. Analyst coverage and earnings management. Journal of Financial Economics 88 (2): 245-271. 


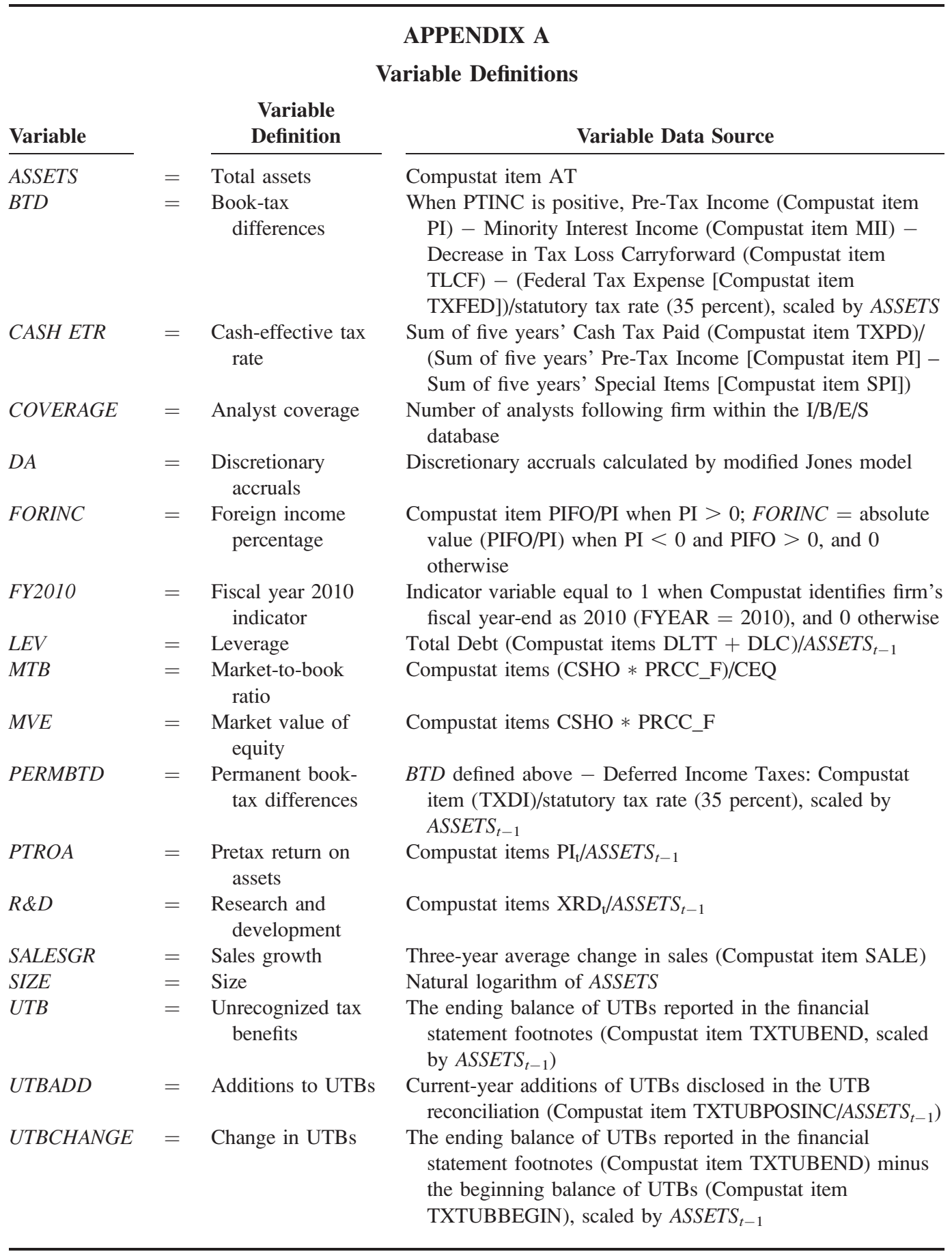

